\title{
Effects of climate, seasonality, and parasitoid abundance on Liriomyza Mik (Diptera: Agromyzidae) populations on important crops in Northeastern Brazil
}

\author{
Viviane R. de Sousa' (D), Paulo C. de Paiva² (D), Daniela M. Takiya² (D), \\ Nívia da S. Dias-Pini ${ }^{3}$ (1) \& Márcia S. Couri (B)
}

\begin{abstract}
1. Departamento de Entomologia, Museu Nacional, Universidade Federal do Rio de Janeiro, 20940-040 Rio de Janeiro, RJ, Brazil. (sousavrodrigues@gmail.com; courimarcia@gmail.com)

2. Departamento de Zoologia, Instituto de Biologia, Universidade Federal do Rio de Janeiro, Av. Carlos Chagas Filho, 373, Cidade Universitária 21941-902 Rio de Janeiro, RJ, Brazil. (paulo.paiva@gmail.com; takiya@gmail.com).

3. Embrapa Agroindústria Tropical, 60511-110 Fortaleza, CE, Brazil. (nivia.dias@embrapa.br)
\end{abstract}

Received 01 June 2020

Accepted 30 December 2020

Published 01 February 2021

DOI 10.1590/1678-4766e2021001

\begin{abstract}
Agromyzidae (Insecta: Diptera) is a cosmopolitan family of acalyptrate flies, with almost 3,000 species worldwide distributed. Most species are leaf miners on a large number of plants. Among them, Liriomyza Mik, 1894 is a large genus of leaf-miner species that can cause significant damage to economically important crops and is considered agricultural pests, such as Liriomyza sativae Blanchard, 1938 and Liriomyza huidobrensis (Blanchard, 1926), which are herein investigated. The present study deals with the impact of climatic factors (temperature, humidity, and precipitation), seasonality, and parasitoid abundance on leaf-miner infestation during one year in five cultivated crops in Northeastern Brazil. Climatic factors for instance had different effects on $L$. sativae populations in melon and watermelon crops. Larval abundances were greater during the dry season for both species, $L$. sativae and L. huidobrensis, and abundance of adult parasitoids followed the increase of mining larvae.
\end{abstract}

KEYWORDS. Leaf-miners, climatic factors, plant-insect interaction.

Agromyzidae (Diptera) is a large family of phytophagous acalyptrate flies, with almost 3,000 known species around the world (ITIS, 2016), more than $75 \%$ of them have larvae feeding on plant leafs. Some species may attack other parts of the plant, such as root and stem of herbaceous plants and seed-head and cambium of trees (Spencer, 1973, 1990). According to Benavent-Corai et al. (2005), approximately 900 species in the world have their host plants known, distributed on more than 140 botanical families. More sporadically, some species can be gall-inducing (SPencer, 1973), as Agromyza Fallén, 1810, Japanagromyza Sasakawa, 1958, Hexomyza Enderlein, 1936 (exclusively galler), Melanagromyza Hendel, 1920, Ophiomyia Braschnikov, 1897, Phytoliriomyza Hendel, 1931, and Phytomyza Fallén, 1810 species (Dempewolf, 2005).

Most species have a specific host plant, however, some occur in more than one species of a single genus (monophagous) or botanical family (oligophagous). Some species are polyphagous, attacking a wide variety of species from different botanical families, and are considered as important agricultural pests (BOUCHER, 2010). Liriomyza Mik, 1894 is a large genus with 456 leaf-miner species (ITIS, 2016), four of them considered truly polyphagous: Liriomyza sativae Blanchard, 1938, Liriomyza langei Frick,
1951, Liriomyza huidobrensis (Blanchard, 1926), and Liriomyza trifolii (Burgess, 1880) attacking a wide range of plant species, and Liriomyza brassicae (Riley, 1885), more restricted to the Brassicaceae family (LONSDALE, 2011).

In Brazil, Liriomyza species occurs on several crops as bean, potato, and tomato being able to attack in the early days of cultivation (GAllo et al., 2002) and also may cause problems on ornamental plants (PARRELla, 1987). The biological control of pest species is hampered due to the protection that the leaf provides to the mine and the scarcity of biological information for their species is also a further difficulty (SPENCER, 1973). Synthetic insecticides and parasitoid hymenopterans have been used for population control of pest species (BOUCHER, 2010).

Currently, the wide variety of insecticides used to control Liriomyza pest species does not affect resistant populations. It is still unknown whether parasitoids are effectively able to control fly populations due to high levels of insecticides in some regions (MURPHY \& LASALLE, 1999).

Liriomyza huidobrensis and L. sativae are currently considered the most serious pests among the Agromyzidae (WeINTRAub et al., 2017). Liriomyza huidobrensis occurs in a large number of hosts and its damage is mainly caused by larval activity and also by the feeding punctures made 
by adult females. Liriomyza sativae, many times mistakenly identified under different species names, has been recorded as a serious agricultural pest, with a large number of crops attacked all over the world. Their pest status may vary over the years and location, but damage may increase due to extensive use of DDT and other pesticides (SPENCER, 1973).

Several environmental factors can affect the metabolism and the development of insects. In general, higher temperatures favor a faster metabolism and relative humidity directly affects development, which can be retarded when the humidity is low and can cause drowning eggs and facilitate pathogen contamination when it is too high (Gullan \& Cranston, 2014). Climate changes have notable impacts on agriculture, by influencing, directly or indirectly, crop plants and their associated pests (PrAKASH et $a l ., 2014)$. In general, climatic factors such as temperature, precipitation, humidity, and wind speed and direction directly influence pest distribution and growth by affecting their rate of development, reproduction, distribution, migration, and adaptation. For leaf-miners, temperature certainly affects growth and development (Tshiala et al., 2012).

Among the many commercially produced plants in Brazil, melon and watermelon crops are two of the main products of large national and international interest, with more than 25 and 31 million tons, respectively, produced in the year 2018 (IBGE, 2018). The climate of Northeastern Brazil favors these plantations, as it has low humidity and little rainfall, favoring production of sweeter fruits (SEBRAE, 2016). Tomatoes are another important crop produced in Northeastern Brazil, and due to the dry climate and low rainfall rates, it can grow almost all year round (COSTA et al., 2019). In 2017, tomato production exceeded 134 million tons in Ceará state, 32 million of them only from Guaraciaba do Norte (IBGE, 2018). Additionally, Northeastern Brazil represents the third most important Brazilian macroregion for ornamental horticulture, with $11.8 \%$ of national producers. The state of Ceará also stands out in the production of ornamental flowers, with roses as the main product. São Benedito has important companies focused on the international market, which stand out in the production of chrysanthemum, gypsophila, among others (SEBRAE, 2015).

The main goal of this paper is to assess the seasonal abundance of L. sativae and L. huidobrensis larvae and their parasitoids on five crops: melon, watermelon, tomato, gypsophila, and chrysanthemum. We also analyzed the influence of climate variables, such as, temperature, humidity, and precipitation on L. sativae leaf-miner populations on melon and watermelon crops in Northeastern Brazil. For the tomato, gypsophila and chrysanthemum crops no investigation on the climatic effects were carried out due to the absence of annual climatic data for these localities.

\section{MATERIAL AND METHODS}

In order to analyze the seasonal abundance of $L$. sativae and L. huidobrensis larvae and their parasitoids, specimen collections were carried out in melon, watermelon, tomato, gypsophila, and chrysanthemum crops in Northeastern Brazil (Tab. I). Melon (Cucumis melo L.) (Fig. 1) and watermelon [Citrullus lanatus (Thunb.) Matsum. \&Nakai] (Fig. 2) crops were located in the municipality of Mossoró (state of Rio Grande do Norte), tomato (Solanum lycopersicum L.) in Guaraciaba do Norte (state of Ceará) (Fig. 3), and gypsophila (Gypsophila paniculata L.) (Fig. 4) and chrysanthemum (Chrysanthemum morifolium Ramat.) (Fig. 5) in São Benedito (state of Ceará). All crops are in the open field, except chrysanthemum in greenhouses.

Collections were carried out bimonthly from November 2016 to September 2017 in the studied sites. For each crop, individual plants were investigated in their intermediate age relative to the total time of development until harvest, except for tomato crops that were investigated independent from age as they are perennials. A total number of ten plants of each crop were randomly selected, and from them, 25 leaves, also randomly selected, were investigated for the absence or presence of Mines. For L. huidobrensis, only information on larval numbers and their parasitoids was used. Population density was based on the number of larvae.

Leaves with mines were detached, stored under styrofoam with refrigerated plates and taken to the laboratory for analysis and count of the number of insect mines, larvae, and pupae, and parasitoid in each leaf. Some infested branches were removed with pruning shears and placed for rearing in the laboratory of Entomology of Empresa Brasileira de Pesquisa Agropecuária, Embrapa Agroindústria Tropical (EMBRAPA) under temperature of $27^{\circ} \mathrm{C}$, until adult emergence for identification of the species.

Tab. I. Information about locality, crops, variety and geographical coordinates in Northeastern Brazil where the collections were carried out.

\begin{tabular}{|c|c|c|c|}
\hline Locality & Crop & Variety & Geographical coordinates, Elevation \\
\hline \multirow[t]{2}{*}{ Mossoró, RN } & Melon & Goldex & $\mathrm{S}^{\prime} 4^{\circ} 03^{\prime} 53.7^{\prime \prime} \mathrm{W} 40^{\circ} 53^{\prime} 34.0^{\prime \prime}-32 \mathrm{~m}$ \\
\hline & Watermelon & Quetzali & $\mathrm{S} 04^{\circ} 53^{\prime} 43.2^{\prime \prime} \mathrm{W} 37^{\circ} 21^{\prime} 36.7^{\prime \prime}-36 \mathrm{~m}$ \\
\hline Guaraciaba do Norte, CE & Tomato & Paron, Janaina & 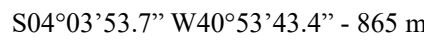 \\
\hline \multirow[t]{2}{*}{ São Benedito, CE } & Chrysanthemum & Omega time golden, Sunny Reagan & $\mathrm{S}^{\circ} 4^{\circ} 03^{\prime} 53.6^{\prime}$ W $40^{\circ} 53^{\prime} 43.4^{\prime \prime}-889 \mathrm{~m}$ \\
\hline & Gypsophila & Dynamic love & $\mathrm{S}_{04}^{\circ} 03^{\prime} 50.5^{\prime \prime} \mathrm{W} 40^{\circ} 53^{\prime} 14.5^{\prime \prime}-855 \mathrm{~m}$ \\
\hline
\end{tabular}




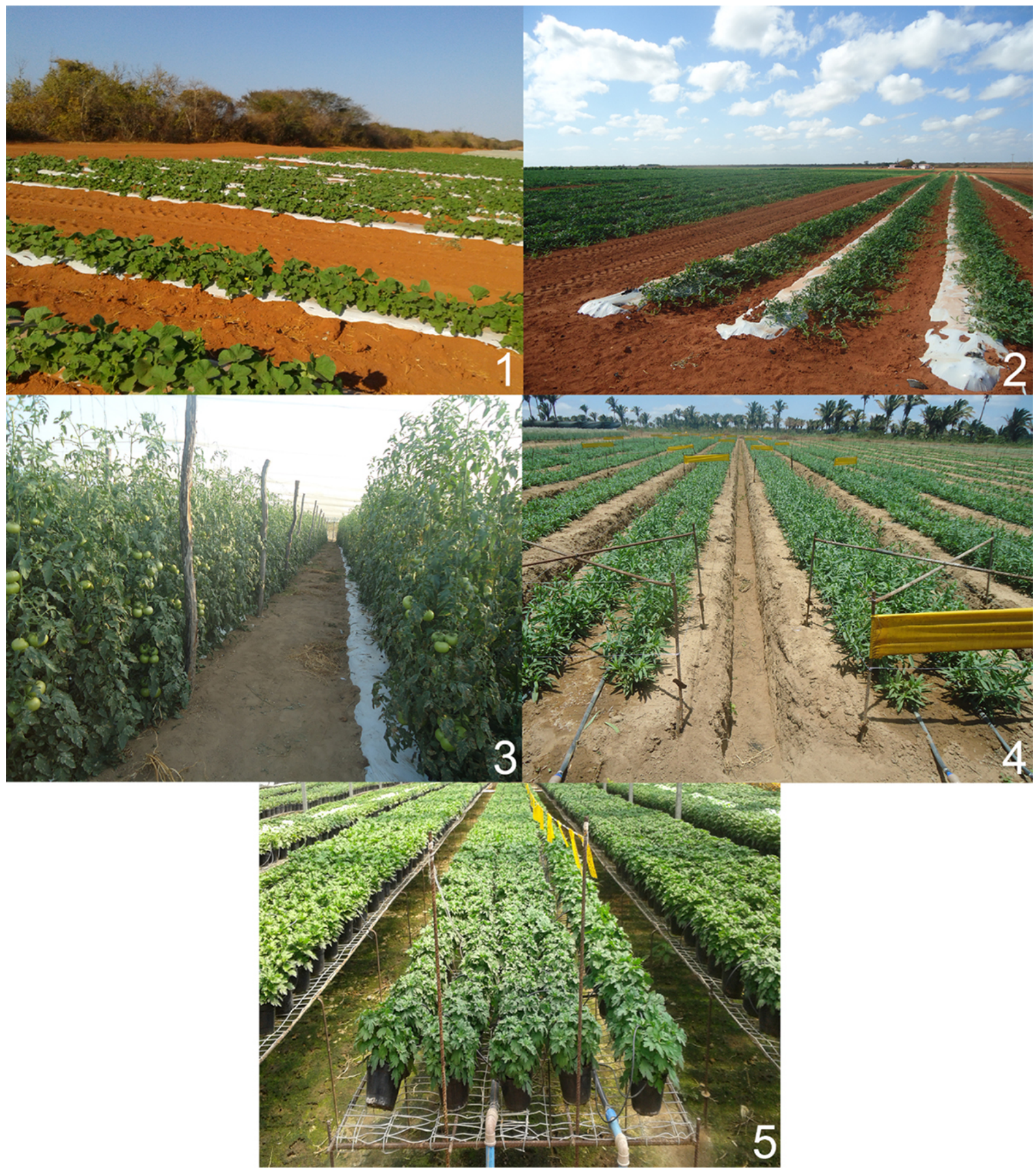

Figs 1-5. Overview of crops. Figs 1, 2, Mossoró, Rio Grande do Norte, Brazil: 1, melon (Cucumis melo L.); 2, watermelon [Citrullus lanatus (Thunb.) Matsum. \& Nakai]. Fig. 3, tomato (Solanum lycopersicum L.) in Guaraciaba do Norte, Ceará, Brazil. Figs 4, 5, São Benedito, Ceará, Brazil: 4, Gypsophila paniculata L.; 5, chrysanthemum (Chrysanthemum morifolium Ramat.).

The identifications of the specimens were made with use some keys and morphological comparisons. Liriomyza sativae was identified on melon, watermelon and tomato crops, while L. huidobrensis was identified on gypsophila and chrysanthemum crops. The material were deposited on
Diptera collection at Museu Nacional, Universidade Federal do Rio de Janeiro.

Meteorological data [minimum and maximum temperature $\left({ }^{\circ} \mathrm{C}\right)$, relative humidity $(\%)$, and precipitation (mm)] were collected from Centro de Previsão de Tempo 
e Estudos Climáticos (CPTEC) of Instituto Nacional de Pesquisas Espaciais (INPE) located at Mossoró (Tab. IV).

The role of climatic variables (Tab. VI) on leaf-miner density (number of leaves with mines, number of leaf-miner larvae and number of parasitoids) was assessed through a Generalized Linear Model (GLM) method with Poisson distribution for each of the dependent variables. All data were analyzed using program R (v.3.5.3.) (R Core Team, 2019). Information on the number of mines on leaves, number of affected leaves, number of $L$. sativae larvae and number of parasitoids (larvae or pupae) have been accounted in melon (Tab. II) and watermelon (Tab. III) crops.

Tab. II. Biotic data of Liriomyza sativae Blanchard, 1938 on melon (Cucumis melo L.) crop from November 2016 to September 2017 in Mossoró, Rio Grande do Norte, Northeastern Brazil

\begin{tabular}{lccc}
\hline Date & $\mathrm{N}^{\circ}$ leaves attacked & $\mathrm{N}^{\circ}$ of larvae & $\mathrm{N}^{\circ}$ of parasitoids \\
\hline November/2016 & 78 & 146 & 8 \\
January/2017 & 110 & 448 & 7 \\
March/2017 & 153 & 745 & 390 \\
May/2017 & 117 & 584 & 7 \\
July/2017 & 110 & 317 & 3 \\
September/2017 & 134 & 1763 & 321 \\
\hline
\end{tabular}

Tab. III. Biotic data of Liriomyza sativae Blanchard, 1938 on watermelon (Citrullus lanatus (Thunb.) Matsum. \& Nakai) crop from November 2016 to September 2017 in Mossoró, Rio Grande do Norte, Northeastern Brazil.

\begin{tabular}{lccc}
\hline Date & $\mathrm{N}^{\circ}$ leaves attacked & $\mathrm{N}^{\circ}$ of larvae & $\mathrm{N}^{\circ}$ of parasitoids \\
\hline November/2016 & 95 & 160 & 6 \\
January/2017 & 83 & 446 & 69 \\
March/2017 & 2 & 0 & 1 \\
May/2017 & 34 & 23 & 3 \\
July/2017 & 56 & 104 & 3 \\
September/2017 & 105 & 1767 & 512 \\
\hline
\end{tabular}

Tab. IV. Meteorological data from November 2016 to September 2017 in Mossoró, Rio Grande do Norte, Northeastern Brazil. The values refer to the annual mean of each month.

\begin{tabular}{lcccc}
\hline \multirow{2}{*}{ Date } & \multicolumn{2}{c}{ Temperature $\left({ }^{\circ} \mathrm{C}\right)$} & \multirow{2}{*}{ Relative humidity (\%) } & Precipitation (mm) \\
\cline { 2 - 4 } November/2016 & Min. & Max. & 31.0 & 1.0 \\
January/2017 & 22.4 & 35.3 & 29.0 & 6.4 \\
March/2017 & 22.6 & 36.4 & 44 & 74.6 \\
May/2017 & 21.7 & 33.7 & 31.0 & 42.8 \\
July/2017 & 21.1 & 35.1 & 25.0 & 63.6 \\
September/2017 & 19.0 & 34.6 & 24.0 & 0.6 \\
\hline
\end{tabular}

\section{RESULTS}

As regards the role of climatic variables on $L$. sativae and L. huidobrensis larvae and their parasitoids for melon and watermelon, results of the GLM analysis (Tab. V) on melon (Figs 6-17) showed that the best model included all variables. Maximum temperatures had significant positive relation with all dependent variables (i.e., number of leaves with mines, number of leaf-miner larvae, and number of parasitoids). Liriomyza sativae density, number of leaves affected, and parasitoid population showed an association with larger thermal amplitudes, since their density was higher when minimum temperatures were lower and the maximum temperatures were higher. On the other hand, leaf-miner density was lower when the minimum temperature was larger and the maximum was shorter (Figs 6, 7, 10, 11, 14, 15). All dependent variables also increased with the increase of the minimum relative humidity (Figs $8,12,16$ ). Precipitation (Figs 9, 13, 17) caused different effects among variables. While higher precipitations caused a positive relation with the number of leaves and larvae, which continued to increase even in rainy seasons; it caused a decrease in the number of parasitoids. 
Tab. V. Generalized Linear Model (GLM) result used to evaluate effects of climate variables on Liriomyza sativae Blanchard, 1938 population in melon crop from November 2016 to September 2017. Values in columns correspond to the coefficient of each explanatory variable in the best model with respective degrees of freedom. Log likelihood and AICc of each model (Tmin, minimum temperature; Tmax, maximum temperature; Rhmin, minimum relative humidity).

\begin{tabular}{lccccccc}
\hline Melon crop & Tmin & Tmax & Rhmin & Rain & df & logLik & AICc \\
\hline $\mathrm{N}^{\circ}$ of leaves & -0.24490 & 0.466700 & 0.071270 & 0.0043140 & 6 & -19.742 & -32.5 \\
$\mathrm{~N}^{o}$ of larvae & -1.1350 & 1.81400 & 0.14880 & 0.005703 & 6 & -24.168 & -23.7 \\
$\mathrm{~N}^{\circ}$ of parasitoids & -1.9810 & 1.5330 & 0.87450 & -0.056110 & 6 & -14.980 & -42.0 \\
\hline
\end{tabular}

Tab. VI. Generalized Linear Model (GLM) result used to evaluate effects of climate variables on Liriomyza sativae Blanchard, 1938 population in watermelon crop from November 2016 to September 2017. Values in columns correspond to the coefficient of each explanatory variable in the best model with respective degrees of freedom. Log likelihood and AICc of each model (Tmin, minimum temperature; Tmax, maximum temperature; Rhmin, minimum relative humidity).

\begin{tabular}{lccccccc}
\hline Watermelon crop & Tmin & Tmax & Rhmin & Rain & df & logLik & AICc \\
\hline $\mathrm{N}^{\circ}$ of leaves & 0.37990 & -0.53860 & -0.28260 & -0.01556 & 6 & -16.497 & -39.0 \\
$\mathrm{~N}^{\circ}$ of larvae & 1.76700 & -1.40100 & -3.41900 & -0.008127 & 6 & -17.816 & -36.4 \\
$\mathrm{~N}^{\circ}$ of parasitoids & -1.3500 & 2.9630 & 0.6880 & -0.04209 & 6 & -12.896 & -46.2 \\
\hline
\end{tabular}
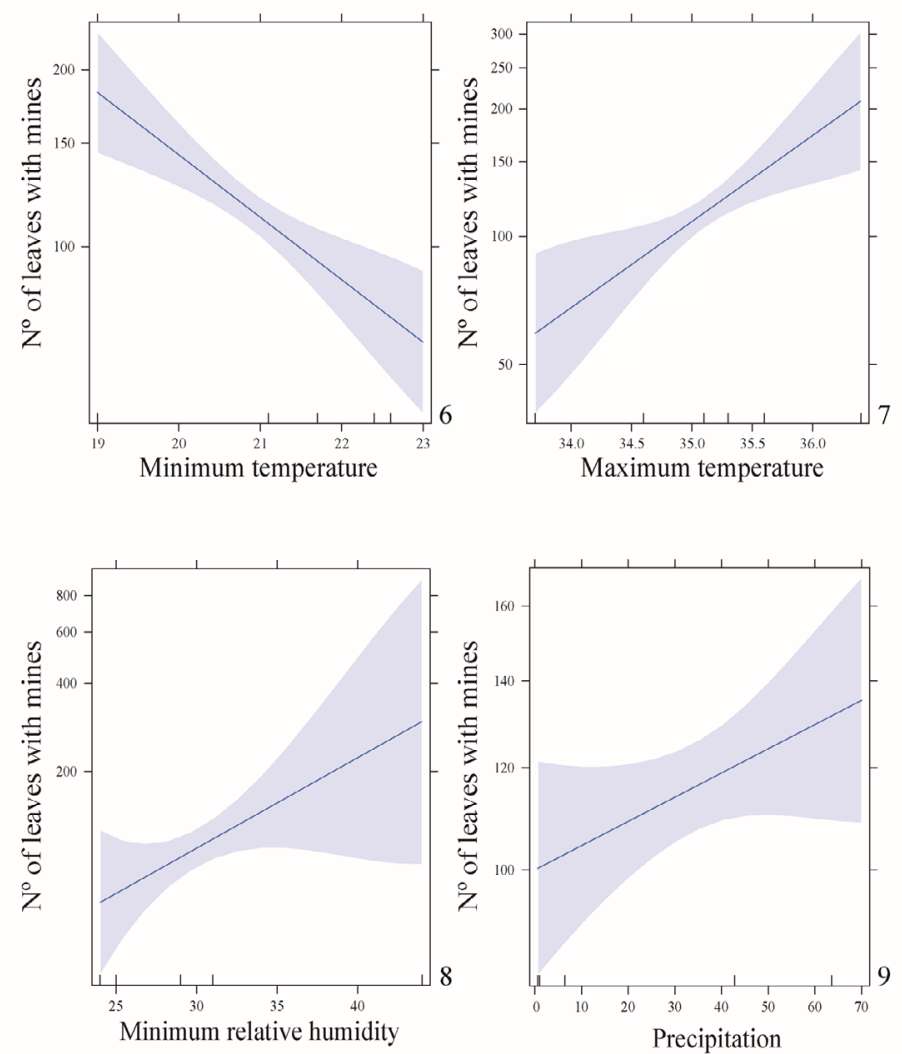

Figs 6-9. Effect of climate factors on number of mined leaves on melon crop: 6 , minimum temperature $\left({ }^{\circ} \mathrm{C}\right) ; 7$, maximum temperature $\left({ }^{\circ} \mathrm{C}\right) ; 8$, minimum relative humidity $(\%) ; 9$, precipitation $(\mathrm{mm})$.

In watermelon crop (Figs 18-29), GLM best model also included all variables, and results showed that the number of attacked leaves was more associated with the shorter thermal amplitudes, so it was higher when minimum temperatures were higher and maximum temperatures were lower. On the other hand, density of mined leaves was lower when the minimum temperature was lower and the maximum was higher (Figs 18, 19). Density of leaf-miner larvae and parasitoids showed a different pattern with higher densities when minimum temperatures were lower and maximum temperatures were higher (Figs 22, 23, 26, 27). Concerning the relative humidity, the number of leaves with mines was higher when minimum relative humidity was lower (Fig. 20 ), while density of larvae and parasitoids were higher when minimum relative humidity was also higher (Figs 24, 28). Precipitation negatively affected all biotic variables that decreased during rainy periods (Figs 21, 25, 29). 

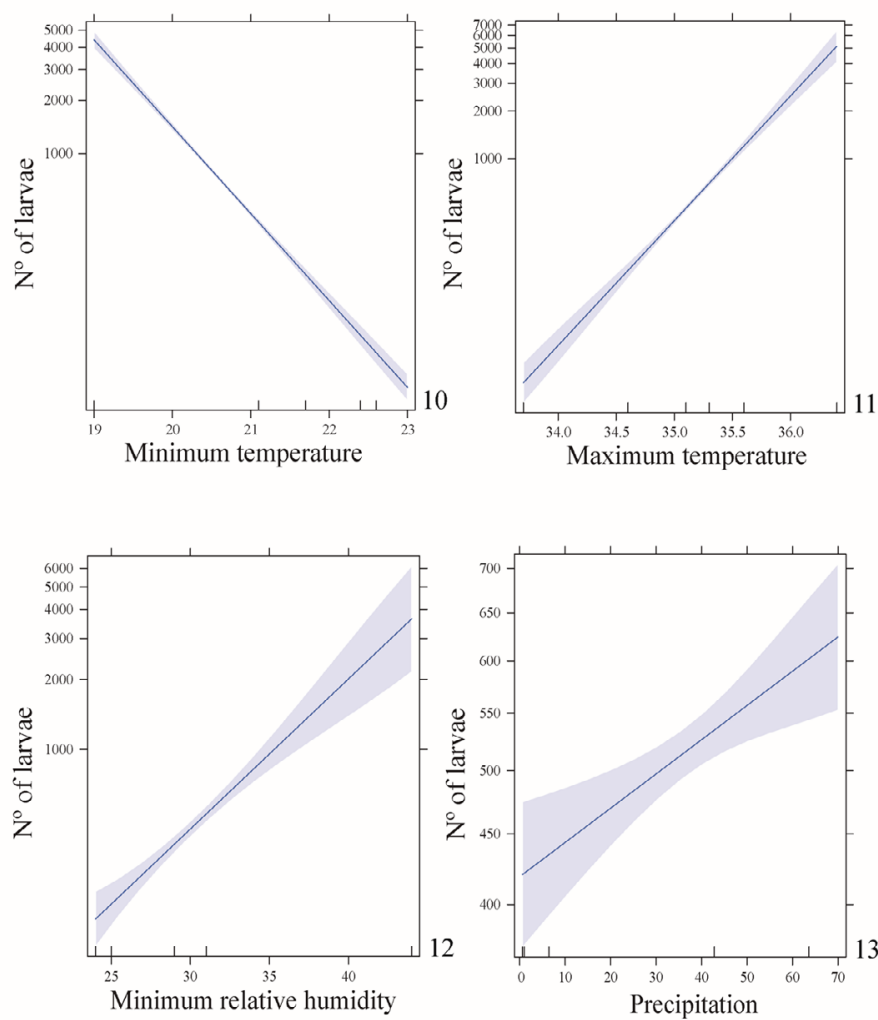

Figs 10-13. Effect of climate factors on number of leaf-miner larvae on melon crop: 10 , minimum temperature $\left({ }^{\circ} \mathrm{C}\right) ; 11$, maximum temperature $\left({ }^{\circ} \mathrm{C}\right) ; 12$, minimum relative humidity $(\%) ; 13$, precipitation $(\mathrm{mm})$.
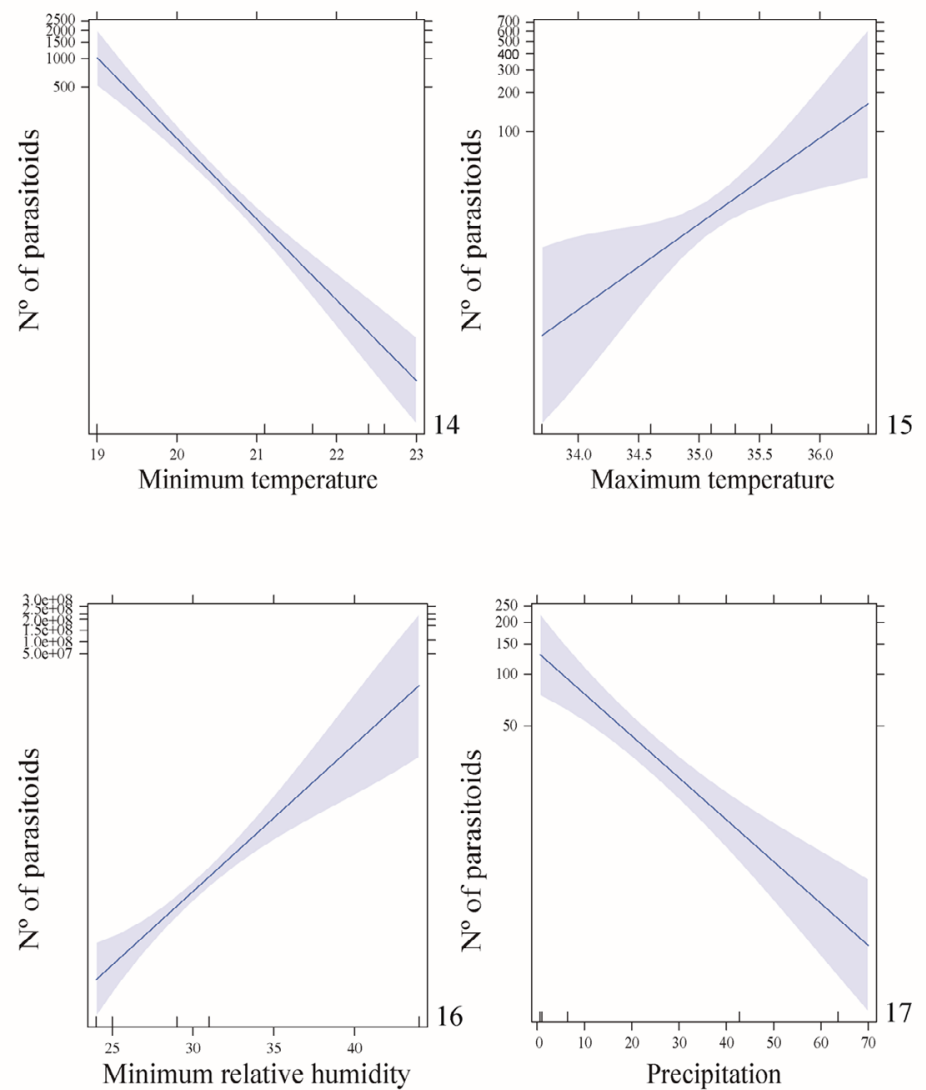

Figs 14-17. Effect of climate factors on number of parasitoids on melon crop: 14 , minimum temperature $\left({ }^{\circ} \mathrm{C}\right) ; 15$, maximum temperature $\left({ }^{\circ} \mathrm{C}\right) ; 16$, minimum relative humidity $(\%) ; 17$, precipitation $(\mathrm{mm})$. 

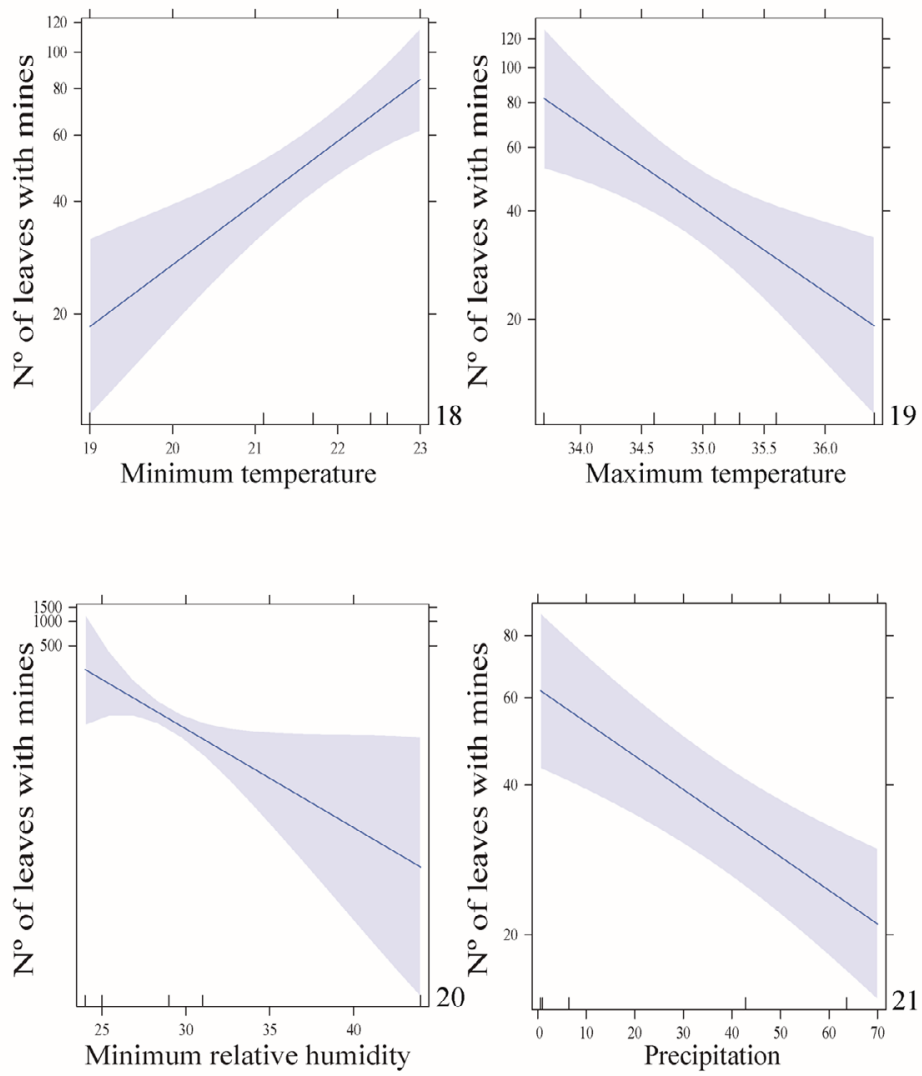

Figs 18-21. Effect of climate factors on number of mined leaves on watermelon crop: 18 , minimum temperature $\left({ }^{\circ} \mathrm{C}\right) ; 19$, maximum temperature $\left({ }^{\circ} \mathrm{C}\right)$; 20 , minimum relative humidity $(\%) ; 21$, precipitation $(\mathrm{mm})$.
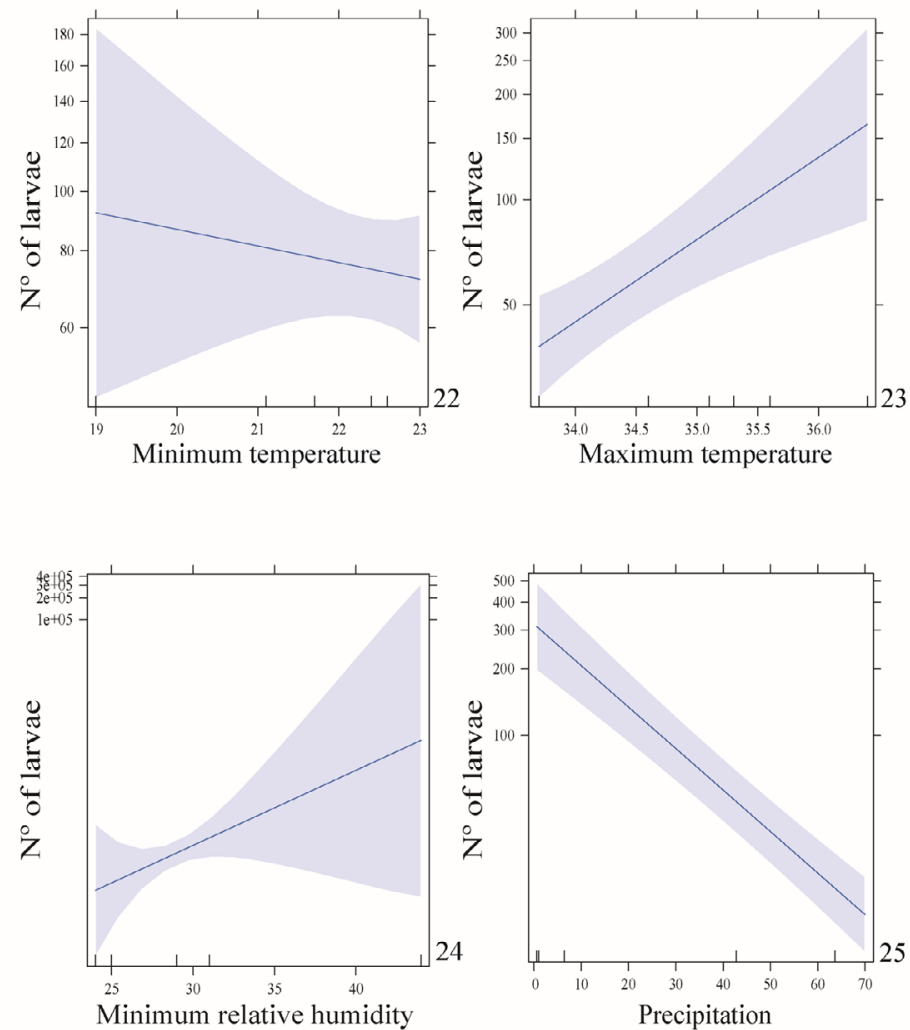

Figs 22-25. Effect of climate factors on number of leaf-miner larvae on watermelon crop: 22 , minimum temperature $\left({ }^{\circ} \mathrm{C}\right) ; 23$, maximum temperature $\left({ }^{\circ} \mathrm{C}\right) ; 24$, minimum relative humidity $(\%) ; 25$, precipitation $(\mathrm{mm})$. 
Regarding the seasonal abundance of $L$. sativae and L. huidobrensis larvae and their parasitoids on five crops, the GLM analysis $(\mathrm{P}<0.05)$ indicated that Liriomyza species were present throughout the year in all crops. In melon and watermelon crops, abundances of $L$. sativae were higher during September in the dry season (Figs 30, 31). In the tomato crop, the highest abundance of $L$. sativae occurred in January (Fig. 32). The abundance of L. huidobrensis on gypsophila was quite similar throughout the year, with a slight increase in the months of July and September (Fig. 33). In chrysanthemum, the population had a small increase in July, May and September (Fig. 34). In general, both $L$. sativae and $L$. huidobrensis infestations had a population increase in the dry season, when the temperature was higher.

The abundance of parasitoids increased in the same proportion as the increase of mining larvae, with $\mathrm{P}$ values $(\mathrm{P}<0.05)$ (Tab.VII) significant for all crops (Figs 35-38). For the gypsophyla crop no parasitism was observed during the collection period.

\section{DISCUSSION}

Regarding $L$. sativae on melon and watermelon crops the larval density showed to be more related to higher thermal amplitudes. According to RoDrigues (2004), the optimal threshold considered for rapid development, with a higher number of offspring for most insects is close to $25^{\circ} \mathrm{C}$. To Costa-Lima et al. (2009), larvae of $L$. sativae can survive under different temperatures from $15-32^{\circ} \mathrm{C}, 30^{\circ} \mathrm{C}$ being the best for their development. Observed temperatures in the present experiment were more or less constant throughout the year, with the maximum varying only from $34.6^{\circ} \mathrm{C}$ to $36.4^{\circ} \mathrm{C}$. Similar to our analyses, results for $L$. sativae on tomato, demonstrated that the rate of infestation exhibited an increasing trend with increasing temperature (Mazumdar \& BhuiYa, 2015). On the other hand, $L$. huidobrensis populations can remain viable at maximum temperatures of $28^{\circ} \mathrm{C}$ (MACVEAN, 1999) and the increasing solar intensity and aridity approaching summer months may trigger estivation, thus allowing them to survive for a long time in subtropical climates (WeINTRAUB et al., 2017).
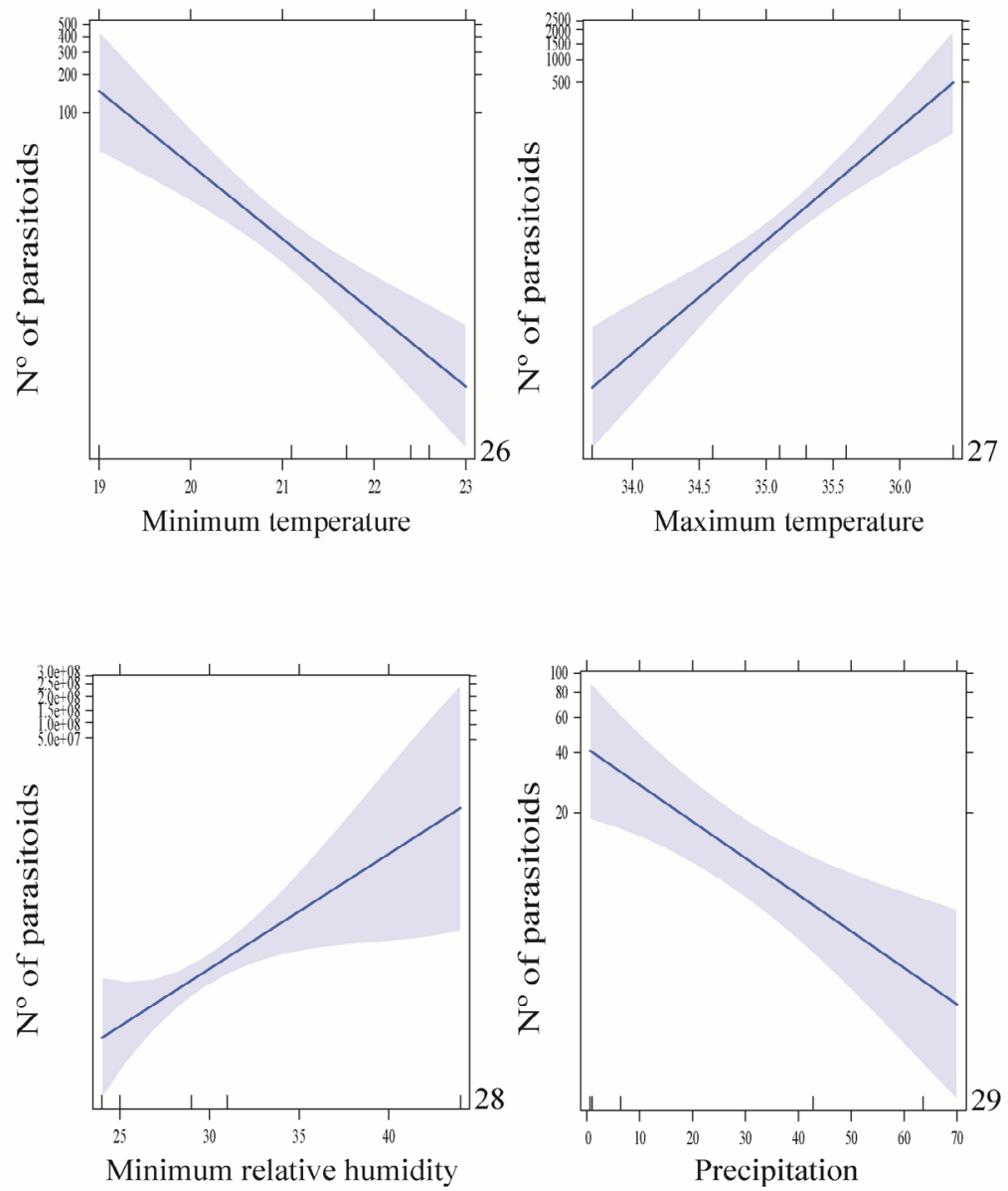

Figs 26-29. Effect of climate factors on number of parasitoids on watermelon crop: 26 , minimum temperature $\left({ }^{\circ} \mathrm{C}\right) ; 27$, maximum temperature $\left({ }^{\circ} \mathrm{C}\right) ; 28$, minimum relative humidity (\%); 29 , precipitation (mm). 

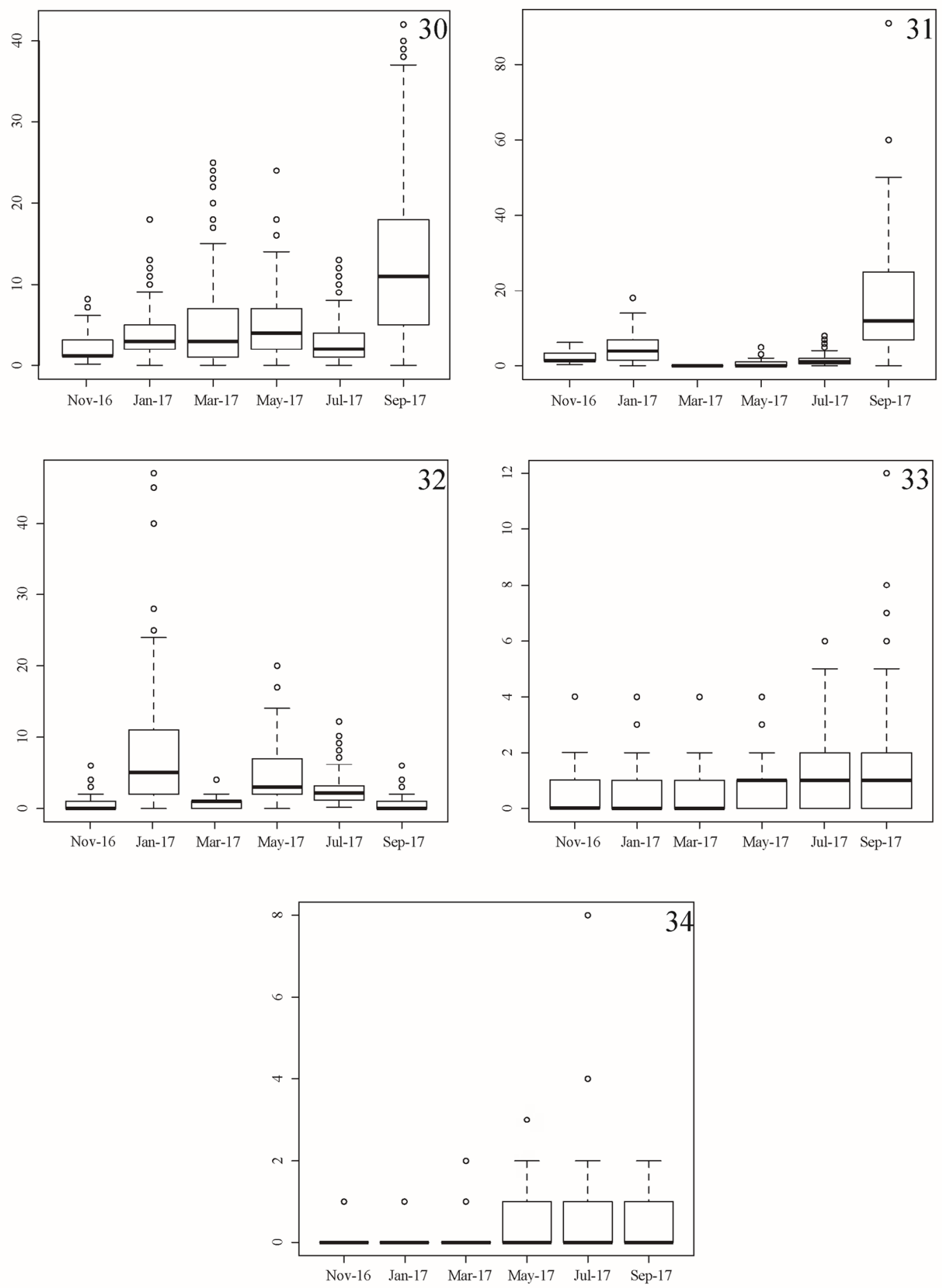

Figs 30-34. Seasonal abundance from November 2016 to September 2017. Liriomyza sativae Blanchard, 1938: 30, on melon (Cucumis melo L.); 31, on watermelon [Citrullus lanatus (Thunb.) Matsum. \& Nakai]; 32, on tomato (Solanum lycopersicum L.). Liriomyza huidobrensis (Blanchard, 1926): 33, on Gypsophila paniculata L.; 34, on chrysanthemum (Chrysanthemum morifolium Ramat.).

Tab. VII. General Linear Model (GLM) result used to evaluate the level of parasitism on fly larvae on all crops from November 2016 to September 2017.

\begin{tabular}{lc}
\hline Crops & P value \\
\hline Melon & $<2 \mathrm{e}-16^{* * *}$ \\
Watermelon & $<2 \mathrm{e}-16^{* * *}$ \\
Tomato & $<2 \mathrm{e}-16^{* * *}$ \\
Chrysanthemum & $<2 \mathrm{e}-16^{* * *}$ \\
\hline
\end{tabular}



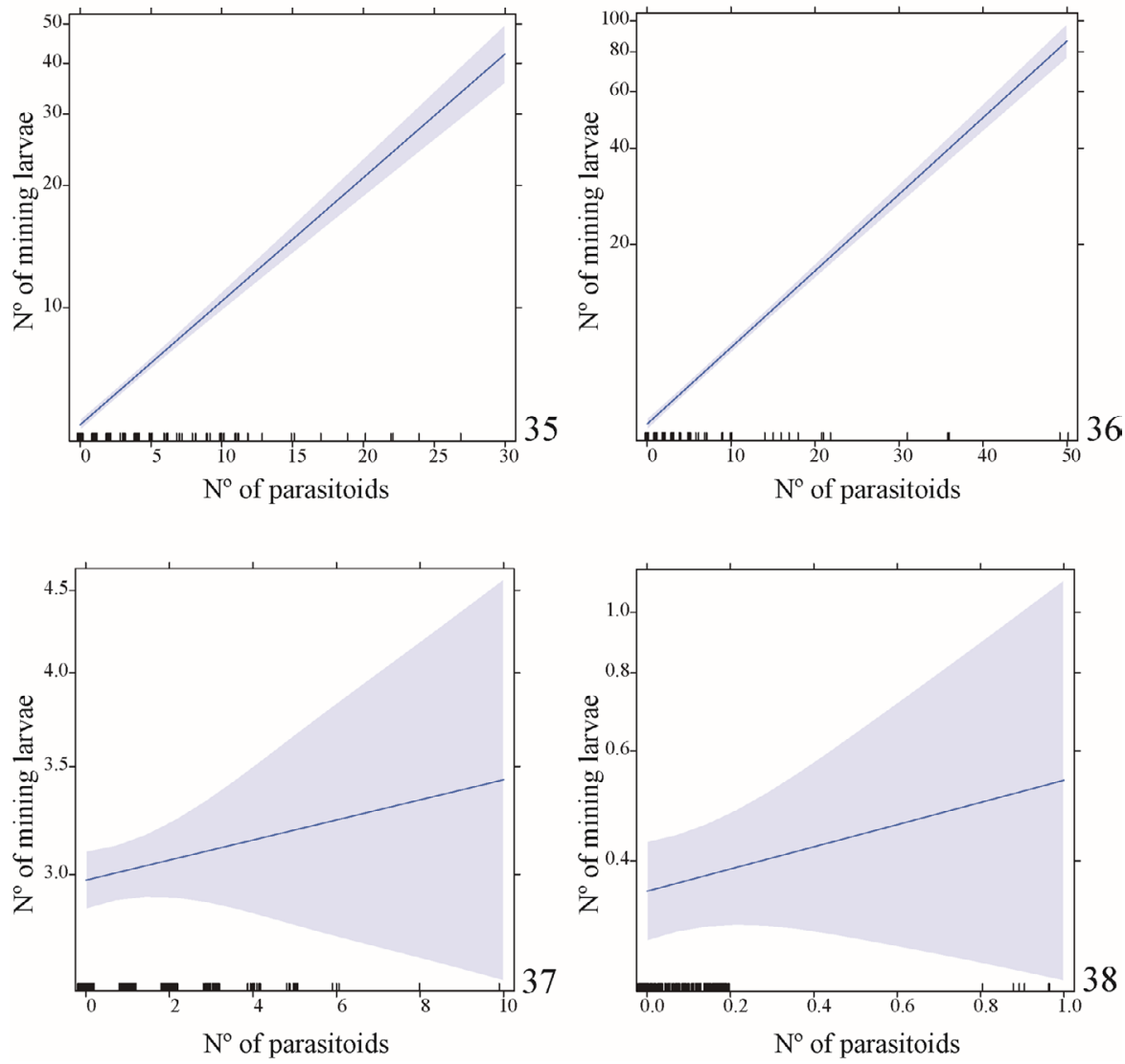

Figs 35-38. Abundance of leaf-miner larvae compared to the abundance of their parasitoids from November 2016 to September 2017: 35, Liriomyza sativae on melon; 36, L. sativae on watermelon; 37, L. sativae on tomato; 38, Liriomyza huidobrensis on chrysanthemum.

For the leaf-miner L. trifolii, studies demonstrated that the temperature, relative humidity, and rainfall had a negative influence on number of mines and larvae, while bright sunshine hours positively correlated with $L$. trifolii incidence (VARIYA \& BHUT, 2014).

Mining insects have an added protection that the leaf provides, a microenvironment protected from the most extreme temperatures and with reduced evaporation and possibly a lower chance of larval desiccation (CONNOR \& TAVERNER, 1997). Ideal conditions on temperature, dampness, and protection from wind are more favorable conditions for Agromyzid infestations (Mazumdar \& BhuiYa, 2015). Our observations showed few differences in how L. sativae density responds to temperature changes even under the same environmental conditions. This may be due to the fact that host insect populations and their natural enemies may respond differently to changes in temperature (PRAKASH et al., 2014), besides that, larval development of leaf-miners also may vary by host plant (PARRELla, 1987).

For both crops, the minimum relative humidity around $25 \%$, started the beginning of the increase of larval density, which continued to increase according to higher relative humidity, different from what was observed by MAZUMDAR \& BHUIYA (2015), where no significant relation with humidity was observed. According to CosTA-Lima et al. (2009), the relative humidity has a more direct effect on larval survival, with an ideal around $50 \%$, while below $30 \%$, the leaves are less turgid, compromising larval development. Persistent high relative humidity, between $83-91 \%$ has a significantly negative impact on the abundance of leaf-miner, especially at the late growth stage (CHAKRABORTY, 2011).

In our results, the abundance of larvae of L. sativae on melon crop continued to increase even in periods with higher precipitation, while the abundance decreased in watermelon crop. Drizzling rainfall had no significant effect on the pest structure. But heavy rainfall within a short period had imparted significant negative effect on leafminer incidence. Number of rainy days however showed insignificant positive effect in all the years (CHAKRABORTY, 2011). A similar pattern, as in our results, in the abundance of L. sativae in watermelon, was found in L. trifolii population on tomato, where the rainfall had a positive and significant effect (Sharma et al., 2013). The population peaks of $L$. trifolii in coffee plantations occurred after a period of low rainfall (SILVA et al., 2015). In other cases, the climatic factors did not affect the population of $L$. huidobrensis as well as the population of related parasitoids (AHYA \& LIYANA, 2018). Generally, most of the climatic factors act independently, 
any change of a single climatic factor can lead multiple effects on pest population (CHAKRABORTY, 2011). Moreover, these differences in climate effects related to leaf-miners populations, especially what we observed in watermelon population, could be attributed by other factors such as types of pesticides used to control the leaf-miner (AHYA \& LIYANA, 2018).

For all crops the largest infestation of both Liriomyza species was observed during the dry season, as well as previously documented with the most serious infestations during the same season (Tran et al., 2007). The presence of parasitoids during all the period of cultivation and the increase of this number in proportion to the increase in larvae. Similar to that observed for L. trifolii on bean that the abundance of the parasitoids was positively correlated with leaf-miner host density (Li et al., 2012).

In general, the population of insect pests can be larger in open field comparing to greenhouse (SRI et al., 2017), as we observed here. In addition, both biotic and abiotic factors may together contribute to the establishment of populations in a host plant and the importance of each factor may vary, taking into account the location, season and spatial pattern determined in each host plant (AвOU-FAKHR et al., 2000).

We conclude that all the climatic factors investigated caused rather different effects on L. sativae populations in melon and watermelon crops. These effects varied according to the crop, though temperature, both minimum and maximum, seems to affect most variations in population density among crops.

For all crops the seasonal abundance demonstrated higher population density during the dry season. The population of the parasitoids on each crop (except gypsophyla) had grown with the increase of the mining larvae, possibly due to the greater availability of host larvae. Population seasonality in both L. sativae and L. huidobrensis was also firstly demonstrated in the crops located in Northeastern Brazil. In addition, it was reported that the abundance of parasitoids corresponded to the abundance of mining fly larvae. We also point out the importance to know the factors that can interfere in these pest populations, in order to establish a pattern that could be used for future studies.

Acknowledgments. We thank the "Reijeres", "Estufa Timbauba" and "Norfruit" companies for the permission to collect. Thanks to Empresa Brasileira de Pesquisa Agropecuária, Embrapa Agroindústria Tropical (EMBRAPA) for research funding. VRS acknowledges a CNPq doctoral fellowship received during this study. DMT is a research productivity fellow from CNPq (Proc. 313677/2017-4) and Cientista do Nosso Estado fellow from Fundação Carlos Chagas Filho de Amparo à Pesquisa do Estado do Rio de Janeiro (FAPERJ, Proc. E-26/202.672/2019).

\section{REFERENCES}

Abou-Fakhr, H. E. M. \& Nemern, N. M. 2000. Population densities, spatial pattern and development of the pea leafminer (Diptera: Agromyzidae) on cucumber, swisschard and bean. The Journal of Agricultural Science 134:61-68.

AhyA, M. N. \& LiYAnA, I. N. 2018. Relationship of leaf miner populations with biotic and abiotic factors in tomato farms in Cameron Highlands. Journal of Tropical Agriculture and Food Science 46(2):107-115.
Benavent-Corai, J.; Martinez, M. \& Jiménez Peydró, R. 2005. Catalogue of the host plants of the world Agromyzidae (Diptera). Bollettino di Zoologia Agraria e di Bachicoltura Series II37:1-97.

Boucher S. 2010. Agromyzidae (leaf-mining flies). In: Brown, B. V.; Borkent, A.; Cumming, J. M.; Wood, D. M.; Woodley, N. E. \& Zumbado, M. A. eds. Manual of Central American Diptera. Ottawa, NRC Research Press. Volume 2, p. 1057-1071.

Chakraborty, K. 2011. Incidence and Abundance of tomato leaf miner, Liriomyza trifolii Burgess in Relation to the Climatic Conditions of Alipurduar, Jalpaiguri, West Bengal, India. Asian Journal of Experimental Biological Sciences 2(3):467-473.

Connor, E. F. \& Taverner, M. P. 1997. The evolution and adaptive significance of the leaf-mining habit. Oikos 79:6-25.

Costa, N. D.; Dias, R. C. S.; Flori, J. E.; Queiróz, M. A. \& Rezende, G. M. O. 2019. Olericultura. Available at $<$ http://www.cpatsa.embrapa. br:8080/pesquisa/oleric.html>. Accessed on November 2019.

Costa Lima, T. C.; Geremias, L. D. \& Parra, J. R. 2009. Efeito da Temperatura e Umidade Relativa do ar no desenvolvimento de Liriomyza sativae Blanchard (Diptera: Agromyzidae) em Vigna unguiculata. Neotropical Entomology 38(6):727-733.

Dempewolf, M. 2005. Dipteran Leaf Miners. In: Raman, A.; Schaefer, C. W. \& Withers, T. M. eds. Biology, Ecology, and Evolution of Gall-inducing Arthropods. Enfield, Science Publishers. Volume 1, p. 407-429.

Gallo, D.; Nakano, O.; Silveira-Neto, S.; Carvalho, R. P. L.; Baptista, G. C.; Berti-Filho, E.; Parra, J. R. P.; Zucchi, R. A.; Alves, S. B.; Vendramim, J. D.; Marchini, L. C.; Lopes, J. R. S. \& Omoto, C. 2002. Entomologia agrícola. Piracicaba, Fealq. 920p.

Gullan, P. J. \& Cranston, P. S. 2014. The insects: an outline of entomology, with illustrations by Karina H. McInnes. 5ed. Chichester, Wiley-Blackwell. 632p.

IBGE. 2018. Levantamento Sistemático da Produção Agrícola. Available at $<$ https:/www.ibge.gov.br/busca.html?searchword=produ\%C3\%A7 $\%$ C3\%A3o+agricultur>. Accessed on November 2019.

ITIS. 2016. Catalogue of Life, Annual Checklist. Integrated Taxonomic Information System. Available at <http://www.catalogueoflife.org/ annualchecklist/2016/search/all/key/Liriomyza/fossil/0/match/1>. Accessed on August 2019.

Li, J.; Seal, D. R.; Leibee, G. L. \& Liburd, O. E. 2012. Seasonal abundance and spatial distribution of the leafminer, Liriomyza trifolii (Diptera: Agromyzidae), and its parasitoid, Opius dissitus (Hymenoptera: Braconidae), on bean in Southern Florida. Florida Entomologist 95(1):128-135.

Lonsdale, O. 2011. The Liriomyza (Agromyzidae: Schizophora: Diptera) of California. Zootaxa 2850:1-123.

MACVEAN, C.1999. Determinación de riesgo cuarentenario de la mosca minadora, Liriomyza huidobrensis (Blanchard), en exportaciones de Guatemala. Consejo Nacional de Ciencia y Tecnologıa. Proyecto 5 FODECYT, informe final. Available at $<$ http://glifos.concyt.gob.gt/ digital/fodecyt/fodecyt \%201997.05.pdf $>$. Accessed on November 2019.

Mazumdar, S. \& BhuiYA, B. A. 2015. Correlation between climatic factors and leafminer (Insecta: Agromyzidae) infestation on three vegetable crops in Chittagong, Bangladesh. Asiatic Society of Bangladesh Science 1(1):1-5.

Murphy, S. T. \& Lasalle, J. 1999. Review article: balancing biological control strategies in the IPM of new world invasive Liriomyza leafminers in field vegetable crops. Biocontrol News and Information 20:91-104.

Parrella, M. P. 1987. Biology of Liriomyza. Annual Review of Entomology 32:201-224.

Prakash, A.; Rao, J.; Mukherjee, A. K.; Berliner, J.; Pokhare, S. S.; Adak, T.; Munda, S. \& Shashank, P. R. 2014. Climate Change: Impact on Crop Pests. Odisha, Applied Zoologists Research Association (AZRA), Central Rice Research Institute. 199p.

R Core TEAm. 2019. R: A language and environment for statistical computing. R Foundation for Statistical Computing, Vienna, Austria.

RodRIGUES, W. C. 2004. Fatores que Influenciam no Desenvolvimento dos Insetos. Info Insetos 4:1-4.

SEBRAE. 2015. Flores e plantas ornamentais do Brasil: série estudos mercadológicos, v. 1. 42p.

SEBRAE. 2016. O cultivo e o mercado do melão. Available at $<$ http:// www.sebrae.com.br/sites/PortalSebrae/artigos/o-cultivo-e-o-mercado- 
do-melao,5a8837b644134410VgnVCM2000003c74010aRCRD>. Accessed on November 2019.

Sharma, D.; Maqbool, A.; Ahmad, H. \& Jamwal, V. V. S. 2013. Meteorological factors influencing insect pests of tomato. Annals of Plant Protection Sciences 21(1):68-71.

Silva, I. W.; Ribeiro, L. H.; Gorri, J. E. R.; Alves, F. M. \& Fernandes, F. L. 2015. First report on the leafminer fly Liriomyza trifolii (Diptera: Agromizydae) attacking coffee plantations. Coffee Science 10(2):262265.

SPENCER, K. A. 1973. Agromyzidae (Diptera) of economic importance. Series Entomologica 9. The Hague, W. Junk, B.V. 418p.

Spencer, K. A.1990. Host specialization in the World Agromyzidae (Diptera). Series Entomologica 45. Dordrecht, Kluwer Academic Publishers. 444p.

SRI, N. R.; JHA, S. \& LATHA, N. S. 2017. Insect pests of tomato and their weather relations under open and cover cultivation. International Journal of Current Microbiology and Applied Sciences 6(9):368-375.
Tran, D. H.; Tran, T. T. A.; Mai, L. P.; Ueno, T. \& Takagi, M. 2007. Seasonal Abundance of Liriomyza sativae (Diptera: Agromyzidae) and its parasitoids on vegetables in Southern Vietnam. Journal of the Faculty of Agriculture Kyushu University 52(1):49-55.

TShiAla, M. F.; BotaI, J. O. \& Olwoch, J. M. 2012. Leafminer agromyzid pest distribution over Limpopo province under changing climate. African Journal of Agricultural Research 7(48):6515-6522.

VARIYA, M. V. \& BHUT, J. B. 2014. Effect of weather parameters on incidence of leaf miner (Liriomyza trifolii Burgess) on tomato. International Journal of Plant Protection 7(1):196-200.

Weintraub, P. G.; SchefFer, S. J.; Visser, D.; Valladares, G.; Correa, A. S.; Shepard, B. M.; Rauf, A.; Murphy, S. T.; Mujica, N.; Macvean, C.; Kroschel, J.; Kishinevsky, M.; Joshi, R. C.; Johansen, N. S.; Hallett, R. H.; Hasan, S.; Civelek, H. S.; Chen, B. \& Metzler, H. B. 2017. The Invasive Liriomyza huidobrensis (Diptera: Agromyzidae): Understanding Its Pest Status and Management Globally. Journal of Insect Science 17(1)28:1-27. 